\title{
Assessments of the Determinants that Affect Women's Participation in Economic Activities: The Case of Bule Hora and Yabelo Districts, Oromia Regional State, Ethiopia
}

\author{
Defaru Adugna Feye (MSc) Edosa Kubsa Lebeta(MSc) \\ Department of Economics, College of Business and Economics, Bule Hora University, Ethiopia
}

\begin{abstract}
An economic activity is a process of producing and or provision of goods and service in economic sectors. Currently, half of Ethiopian peoples are females; which imply their role is great in economic activities. This study aimed to investigate the participation of women in economic activities and the factors that affect them in at the study area. To achieve the objectives of the study primary data was collected from 374 sample size based on 136585 estimated number of women of the districts in 2011/2012 E.C.; descriptive and econometric approach were used in analyzing the collected data. Even though women had been great a role in the economic growth, their participation were faced hindrance such as low level of training and traditional attitude toward business at the study area. The model used estimates that as the number of children increases by one, their participation is 0.6 times as likely to dis-occur among households. It was recommended that the government and others stakeholders should give awareness on the attitude of women toward business, family planning and train women on business in order to improve the participation of women in economic activities at the study area.
\end{abstract}

Keywords: Binary Logit Model, Economic Activities, Women, Family Size

DOI: $10.7176 / \mathrm{JESD} / 12-11-01$

Publication date: June $30^{\text {th }} 2021$

\section{Introduction}

"Dubartiin: haadha, obboleettidha, utubaa manaati, amaanaa Waaqayyooti"

The total population of the world is approximately 7.4 billion, over 4.5 billon of which is engaged in different economic activities. Among those women ${ }^{2}$ constitute $49.6 \%$ of the world's total population. In addition to these women make up $40 \%$ of world's work force in agriculture, quarter in the trade and industry and one third in the service sector. This participation of women increases the economic productivity by $30 \%$ in Africa and $54 \%$ in the developed nations (CIA, 2017). This figure shows that women have significant impact on the economy. In many African countries, in all economic sectors women have been marginalized, even tour guides are mainly men practically. For example, in 2015, in Botswana, about 66 guides were women; in Kenya, the Professional Safari Guides Association estimated that 300 of 4,000 guides were women; and in the United Republic of Tanzania, fewer than 10 of about 2,000 guides were women. By contrast, in Rwanda, with regard to mountain gorilla guides and trackers, 11 of 70 guides were women (the Telegraph, 2015).

Women tend to be disproportionately engaged in the most vulnerable and poorest paid activities and are challenged by vertical segregation, unequal pay, discrimination and less access to finance and education. However, women active in tourism appear to face better odds than in any other sector. Women in return contribute significant benefits to tourism itself - actively encouraging female participation in tourism can improve tourism product diversification and the protection of local cultures and environments (UN, 2017). Female participation can be boosted by providing training to increase the choice of jobs available to women and their chances for promotion, and by improving working conditions to promote the well-being of women in lower positions. Women's entrepreneurship should also be encouraged to better harness their skills, to promote innovation in the sector and growth.

Ethiopian women are actively involved in all aspects of their society's life. Women are both producers and procreators and they are also active participants in the social, political and cultural activities of their communities. However, the varied and important roles they play have not always been recognized. The discriminatory political, economic and social rules and regulations prevailing in Ethiopia have barred women from enjoying the fruits of their labor without equal opportunities. Thus, they have lagged behind men in all fields of self-advancement (ILO, 2016). Economic development is unthinkable without the participation of women. In some economic sectors women even constitute a proportionally larger group of the labor force than men. However, their participation in the economy has not been valued. Ethiopian women have not received their fair share of the nation's wealth (ibid, 2016).

\footnotetext{
${ }^{1}$ It is one of a proverb of Oromo which deeply explains the identity and the function of women in Oromo community. Which means women are mothers, sisters, pillar of household and the gift of God.

${ }^{2}$ Women is the plural form of woman; a woman is a female human being. The word woman is usually reserved for an adult; girl is the usual term for a female child or adolescent. In this paper the researchers used for woman as an adult female.
} 
In the world, Ethiopia is considered by many to be one of the most under- developed nations in the world. According to the World Population Data (2018), currently the population of the country is estimated to 107.53 million, which ranks the country $14^{\text {th }}$ by population size in the world. This put the country in the continent of Africa the second-most populous country after Nigeria. Additionally, from nine regional states of Ethiopia, Oromia Regional State, where the research was conducted, is the most populous in the country and females cover $49.64 \%$ from the total population of the region (CSA, 2007). Thus, studying about female mean that investigating, analyzing, and examine about half the population of the country.

\section{Statement of the Research Problem}

According to the survey results, 51 percent of children aged 5 to 17 years are engaged in economic activities. Most of them live in Amhara (64 per cent) and Oromia (54.4 per cent). Boys were more involved in economic activities than girls, especially in the rural areas where respectively 67.8 per cent and 46.5 per cent were working (CSA, 2015). This implies that girls (part of female) are more participate in non-economic activities than boys.

Women's economic empowerment is a prerequisite for sustainable development and proper growth. To success the role of women participation in economic activities, it requires the sound public policies, a holistic approach and long-term commitment and gender specific perspective. This must be integrated at the design stage of policy and programming for women to have more equitable access to asset and services (Gashaw, 2015).

Women in Ethiopia are engaged in various economic activities. Their participation is divided in to three main economic sectors from the total labor force of women 40\% engaged in Agriculture, 25\% in service sector, 20\% in trade and industry and the $15 \%$ are engaged in different formal and informal sectors. However, the participation rate of women in different economic sectors is limited (Selamawit, 2015).

According to Aguilar (2011), in the past few years ago the role of Oromo women within Gada is great but it has been "unrecognized and devalued" (Kumsa, 1998:155). Also, the other researcher write as, "even if women actively participate in the ritual aspect of the Gada generation grade system, but they are marginally involved in political activities" (Dejene, 2009). Overall, women have active roles in ritual practice of the Guji society. Similar to the Borana (a related Oromo branch), however, men control the political spheres of their society.

Female-headed households benefit even less from the expanding agriculture and increasing land tenure change. Studies in Africa demonstrate that privatization of land privileges certain groups such as community leaders and household heads to the detriment of women and some minority groups (Cornhiel, 1997: 1318). Divorced or widowed women are constrained by multiple factors such as prevailing gender ideologies, lack of bargaining power in the public sphere controlled by men, and lack of male labor.

Additionally, among subsistence producers, female-headed households are the most disadvantaged in terms of resource and labor endowment. In fact, divorcees and widowed women are known as hadha iyyessa, poor women, among the Guji. In recent years there has been an increase in the number of hadha iyyessa in the Guji area (Dejene, 2009).This implies that women's economic participation is not as expected relative to men. In other words, their contribution is neither valued nor reported because of the deep-rooted socio-cultural practices and their low educational status.

In general, the researcher identify the following gaps regarding to importance of the title in conducting the research at the study area: the first, from the experience of the researcher as who live within the community, many of local women did not participate in the modern economic sectors like private institutions, NGO, federal level the government institution, regional state level the government institution and even in the zone level their participation is present on low level. Also, physically the researcher observes the local women (Guji and Borena Oromo women) who has their own business at the local and participate in business were very low. The second, there is no any research that is conducted on the determinants of women's participation in economic activities in West Guji and Borana Zone. The third, what makes different from the previous researcher on the other area or country as the study is that the previous researcher title were more related to empowering women which, were more politics while our study is mainly related to the factors which affects women participation in economic activities which concerns economic sector. Fourth, according to Central Statistical Agency, 2015 data gathered from Amhara and Oromiya Regional state indicates boys age from 5 to 17 were more participated in economic activities than girls. This evidence indirectly implies, in both regional state girls were more participated in non-economic activities than boys. Thus, the researcher wants to identify challenges that affect females in the participation of economic activities.

The major questions answered by the results of the research are the following:

1. What are the backward (traditional) conditions which affects the women participation in economic activities?

2. What are the major constraints those limit women's participation in economic activities in the study area?

3. What are the key roles of women's participation for economic development of the study area?

The study was have numerous importance, among those the following are the potential significances. It was be important to create awareness and to narrow the knowledge gap on the determinants and constraints of women's participation in economic activities in the study area. Also, it will be a sound reference for the future researcher to 
conduct researches in the issue either in the same area or other areas of the country. Additionally, the research output will contribute new things to policy makers to design policies on the issues and interests of women mainly in the economic sphere of the society.

\section{Review of literature}

\subsection{Theoretical Review}

\subsubsection{Concepts of Women's Labor Force Participation}

Women have the potential to change their own economic status as well as that of the communities and countries in which they live. Yet, more often those women's economic contributions are unrecognized. Their work is unvalued and their promises are unnourished (Kellerman, 2016).Women's economic empowerment, that is their capacity to bring economic change for themselves, is viewed as the most important factor contributing to achieving equality between women and men. But economically strengthening women who are half of the world's work force is not only a means by which to spur economic growth but also a matter of advancing women's human rights. When governments and communities invest in women, they work to eliminate inequalities. Developing countries are less likely to be plagued by poverty in the entire nation is also make better their chance of becoming strongest players in the global market place (Todaro, 2012).

According to Todaro (2012), the following are some of the positive outcomes of women's economic empowerment; when women's participation in labor force grows fastest, the economy experienced largest reduction in poverty rates; additionally, when women farmers can access the resources, they need their production increases; making it less likely that their families are hungry and malnourished; also, when women own property and earn money from it, they may have more bargaining power at home. This in turn can helps reduce their vulnerability to domestic violence and HIV infection?

When women access to time saving technologies, such as a foot pedaled water pump or a motorized scootereconomic benefit can follow craw research has found that technology helps women increase their productivity as well as launch income generating pursuits and to more effectively contribute to their families, communities and countries. Constraints of women's participation in economic activities in which African women have been participating in the development processes have not enabled them to enhance their capacity, to utilize their physical and intellectual energies in promoting sustainable development. Three areas considered to have limited women's contribution to sustainable development are policy environment, socio- cultural setting and women's incentive (UNICEF, 2017).

\subsubsection{The Nature of Males and Females}

A common interpretation of the behavior and relation between, men and women emphasized the importance of the biological maternal function of the female in determining the nature and content of her being. A women's early life is a preparation for becoming, and her later life is devoted to being, a successful wife and mother. Her activities, though not necessarily confined to the home, at least center around it, for her primary mission is to be a helpmate to her husband and to provide a warm and safe haven for her family. If she does work for pay, she will do best in jobs compatible with her household responsibilities and her feminine personality (Blau\& Ferber, 1992).

Men, on the other hand, are not constrained by their paternal function from fully entering the world outside the home. On the contrary, their natural role as provider and protector spurs them on to greater efforts (Ibid). Thus, nature by itself has an impact for women for not to be influential to outside work and not make women more competitive in their assigned position.

\subsubsection{Feminism Theory}

This study is informed by the liberal strand of feminism. This theoretical framework, in collaboration with other strands of feminism, has given rise to a large body of knowledge, which attempts to explain gender inequalities and the subjugation of women. Liberal feminists tend to focus their energies on establishing and protecting equal opportunities for women through legislation and other democratic means. This theory seeks to achieve the emancipation and empowerment of women through the existing system of bringing about reforms in a gradual way. It is both a theory and a movement which challenges all forms of prejudice in the contexts of patriarchy and capitalism. It agitates and advocates for the recognition of women as humans equal to men and the consequent abolition of privileges and prejudices that follow the possession of any biological reproductive organ (Oakley, 1981).

Korda (1974) posits that most men believe and perceive women as mainly concerned with things that are not serious, characterized by a propensity to emotional response rather than thought. Women are also considered to be weak and having limited ambitions. The consequence is that women are elbowed out of decision-making and are "naturally" subordinated to men. The unshackling of women from male domination, as well as restoring their full humanity account for feminist's preoccupation to fight gender discrimination. There is need for gender equity in economic, social, and political development as pointed out by feminist liberal theory.

Land tenure system, for instance, is based on discriminatory policies. While most African states have considered agriculture the backbone of their economy and acknowledge the significant roles of women in the 
Agriculture sector. Few have paid much attention to the land tenure system which has been discriminating against women. Women's access to loans and other credit facilities for agricultural improvement has been constrained by their inability to own land (WB, 2015).

Educational policies and plans have also limited the ability of women to fully utilize their intellectual energies in management of their economies. Very few women have access to institution of higher education and who do joint to specific stereotyped fields (Henslin, 2013).

Besides the policy environment, women have also constrained by socio-cultural norms through which they are perceived as inferior and second-class citizens, although the position of African women in traditional societies remain undocumented. There has been the tendency to use culture and tradition to undermine that position of women. This has had negative impact in promoting sustainable development. Culture has been used to justify the subordinate position of women in the house hold which excludes them from property ownership. Culture has also been used to justify the existing unequal division of labor. Some cultural norms concerning age of marriage rights have also limited women's participation in formal schooling (Henslin, 2013).

All over the world the significance of the engagement of women in different work places over the past three decades has produced transformation in frameless society's in the economic and urban life since the late 1950. Men's economic activities have been steadily increasing in the economy where women produced $80 \%$ the food and in Asia 60\% and in Latin America 40\% in many cases. This shows that women not only the preparing food but they are effective in other sectors as well. This gives them a well-developed knowledge of the total market and in customers. The participation of women in the labor market has grown by $15 \%$ in East Asia and Latin America between 1971 and 1995 a rate faster than men and the gender gap in wage has narrowed as well (WB, 2012).

\subsubsection{Constraints on Women's Effective Economic Roles}

According to Gashaw (2005), there are many constraints that hinder the effective role of women in economic development. Among these obstacles the most and often still unsolved problem is the traditional back ward attitudes, belief and customs of the society towards women which are continued as a historical legacy across the country. This traditional back ward attitudes towards women(assuming women as a weaker sex, second citizens, dependent, passive and ignorant)are not only hinder and make the effective role of women in visible and unrecognized, but also it make and force women's to internalize and accept their weakness and for long period even still remain un confident. Even though, the government tries to change the attitudes of the society through different mechanisms it is not eradicated and remain difficult. In general, the following are considered as common barrier and often make the role of women unrecognized and insignificant: low level of educational back ground, lack of initial capital to start their own business, lack of business know how, lack of monitoring women's corporation activities, dependency of family on women, lack of interest to work in group (corporation), women's dependency on men's income, and lack of confidence and inferiority.

\subsubsection{Women in Ethiopia}

Ethiopia remains one of the world's poorest countries; its population exceeds 91 million people. Recently Ethiopia is experiencing fatly growing economy. Ethiopians are struggling with poverty and slow increasing rate in the economy. This situation is further complicated by deep traditional, social and economic pattern that place powerful constraints on the rights of women and their opportunity to direct their own lives or participate in and contribute to communities and national development. Women in Ethiopia, like many other developing countries have very low access to economic resources and education. Therefore, women's participation in economic activities generally and in self-employment specifically is limited. The major problem for women to be self-employed was the lack of capital. Many women in Ethiopia are dependent on their husbandse salary coupled with low income levels do not even satisfy monthly expense which force them to engage in work. The second obstacle for women entrepreneurs is lack of skills. The lack of awareness about institutions, like WISE, that helps women's participation in economic activities. Other obstacles for women's participation in economic activities are access to working place and shortage of raw materials Over 85\% of women in Ethiopia reside in rural areas, where peasant families are engaged primarily in subsistence agriculture(WEE, 2013). Rural women are integrated rural economy. This is basically labor intensive and which asks a heavy physical toll on all including children. The revolution had little impact on the lives of rural women.

An improvement in economic coordination would improve the standard of living of women. But real change would require transformation of the attitude of government and men regarding women and their interests ${ }^{\text {ee }}$ and issues (EWA, 2013). There have been some changes in the issues of women in the urban areas where education, health care and employment outside the home have become more available. Although, a few women with a higher education have found professional employment, in most of low paying jobs, like about $40 \%$ of employed women in urban areas work in the service sector mainly in Hotels, Restaurants and Bars. According to the 1976 government survey employment in production and related areas (such as textile and food processing) are accounted for about $25 \%$ of the female work force, followed by sales which accounts for about $11 \%$. The survey also shows that women work in Addis Ababa earned about quarter of the wage earned by men for the same type of work. This difference existed despite the 1975 proclamation step waiting equal pay for equal work for men and women 
(Selamawit, 2012).

The Constitution of the FDRE prohibits harmful laws, customs and practices that oppress or cause bodily or mental harm to women. The Constitution stresses on the importance of gender inequality as a basic requirement for the full realization of all other rights and human freedoms. It has also devoted a separate provision dealing with the rights of women and aiming at addressing the widely prevalent gender biased attitudes and practices. Related sub-articles of Article 35 with the issue under discussion are explained by diagram as below:

Fig. 2.1. The right of women according to FDRE

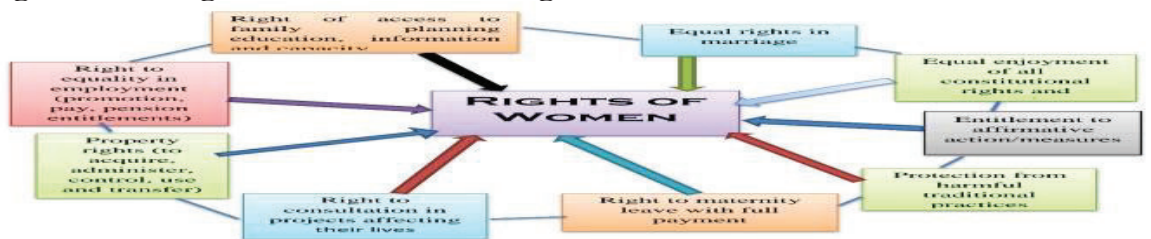

Source: Right of Women Designed by the Researcher, 2019

As try to mention above, FDRE Constitution (1995) give focus for women deeply which was explained under article 35. According to this, women have equal right with men in decision making, participation in social, economic and political activities. For instance, article 35, sub-article 7 and 8 is about economic right of women: which is, the right to acquire, administer, control, use and transfer property. In particular, they have equal rights with men with respect to use, transfer, administration and control of land. They shall also enjoy equal treatment in the inheritance of property. And women shall have a right to equality in employment, promotion, pay, and the transfer of pension entitlements. Additionally, undertake studies regarding special government assistance to be given to women, in particular in the field of education, training and employment, so that they should be able to have equal participation with me $\mathrm{n}$ in political, economic, social and cultural activities; and follow up the implementation of same upon approval (PDEO, 1995).

\subsection{Empirical Review}

Credit services are linked to agricultural inputs, fertilizer, improved seeds and pesticides, that are associated with land endowment and other resources required for agricultural production, marginalizing poor farmers mainly women as they are mainly known as resource poor. Women's access to agricultural sector credit stood at 12 percent of total (MoWA, 2015). Women-owned business, by and large do not show growth in capital or change in type of business. Income generating activities for women focus on small-scale trade in urban, gardening, poultry production and some animal husbandry in rural areas. Due to the lack of resources for the initial credit and savings contributions, poor women do not benefit from the activities (ILO, 2015). The economic empowerment for women asks three things more money, more status and more decision-making power. With up to $45 \%$ of the poorest women in developing countries exercising no control over their income. Economic empowerment is a crucial first step towards greater equality (UN, 2016). In Ethiopia, approximately 27 million people are living in poverty given the lack of access and control over resource and money. Due to discriminatory traditional customs, women compare a majority of those living in absolute gender differentials persist at all levels. As social indicator $75 \%$ of women are illiterate. Even though primary education is being promoted early marriage of girls reduces their chance of having access to higher education (75\% of Ethiopian girls marry before the age of 17 and approximately $13 \%$ between the age of 17 and 21 years). The rate of girls ${ }^{e e}$ student's dropout is much higher than boys and girls often responsible for many chores which may interfere with their schooling (Andrew, 2016). Women discretionally bear the burden of poverty in Ethiopia which is a result of the gender division of labor and lack of access and control over resource. The government demonstrates its firm commitment to equitable socio- economic development of women with the establishment of the national policy of women in 1993 in the permutation of other new constitution in 1995. The national policy on women aims to institutionalize the political and socio-economic rights of women by creating appropriate structures in the government institutions.

According to Mesfin (1997) the students conducted to make more sufficient their work and be aware of their problem they need to have skill through training. Discussion networking and other possible means should be carried out to bring out their potential and work in their full capacity. This is to materialize the advancement of women at all level to building the capacity of all the stake holders and the women themselves through resource establishment, appropriate infrastructure, etc. is mandatory step towards achieving their goals. Majority of the low wage earner in the urban areas are women. In the factors for instance, women make up 30\% of labor force, where as their share of the labor force whereas share of total salaries paid is only $21 \%$. Although, every small number of women hold high position job that require college training and technical knowhow, but Ethiopian women are engaged in all types of old activities. This includes low income job, such as selling Injera (the pancake, like traditional food) and Tela (traditional beer wary), working as house maid is the first occupation most round women who make to either rural area in search for a better life (Ministry of Labor and Social Affairs, 2016).

Prostitution, for example is an occupation frowned up on by all societies depending to women's a 
manifestation of backwardness breeding ground for many kinds of disease and social evils. However, as tag kindly large number of Ethiopian women drives their lively hood from it. Because they have alternative employment opportunities. To sum up, urban women are engaged in such low paying jobs in the informal sector as well as in the formal sector (Ibid, 2016).

Belayneh (2015), finding show different conclusion. firstly, as a suggested by respondents there are some constraints that limit women's participation in the economic activities, such as lack of access of credit financial problem, lack of incentive, legal and regulatory barrier and lack of education. Secondly, the study was made to assess the difference between participant and non-participant women in the economic activity in terms of exploratory variables, such as income, building asset, housing improvement and access to education and also the study show economic participant have better living standard than non-participant women. Thirdly, as a whole economic women participation in economic activities has direct impact on promoting growth, reducing poverty, helping future generation, promoting efficiency and sustainable development. Finally, the study was made also to asses government's function towards giving solution the problem there by enhancing women's participation in economic activities some of the functions that enhance women's participation are facility credit promoting income generating activities giving farming for women key activities that undertaken to enhance economic participation of women.

The other researcher's main findings show that, the roles of women, among other things, includes saving, family planning, efficient utilization of resources, productive, reproductive, and community managing role (Ayferam, 2015)

The other hand, a researcher's findings showed that women's family determine how successful they are going to be in running the business enterprise most especially the aspect of getting support and combining their house work with their business activities. Also, it was revealed that some socio-economic factors act as impediments to growth of a woman entrepreneur because they become successful if they worry less about the attitudes of society (Akerlof, 2011).

The study identified inaccessibility to land; lack of access to water lifting equipment; inadequate technical know-how; poor access to fund and high cost of inputs were the major challenges faced by female vegetable farmers in the State. The study concludes that the yield level in vegetable production among female farmers can be raised if the female farmers were given title to land ownership, have access funds to owned water lifting equipment and given periodic training in irrigation farming. The study also revealed that vegetable production is a profitable enterprise to increase farmers' income in the State (Bilkisu, et al, 2016).

Additionally, the finding of the study exhibited socio-cultural attitudes; lack of asset, gender inequality, religion factor, lack of collateral to access to credit were significantly associated with challenges of women socioeconomic development and there is traditional belief that considering women as weaker section of society (Duressa and Megersa 2018).

\subsection{Conceptual Framework}

The research addressed various types' constraints and in order to achieve the objective of the study, researcher developed conceptual framework as depicted in figure below:

\section{III.Aim and Objective Of Study}

\subsection{Objectives of the Study}

\subsubsection{General Objective}

The general objective of the study is to investigate and analysis the determinants of women's participation in economic activities in Bule Hora and Yabello District.

\subsubsection{Specific Objectives}

In line with the general objective the specific objectives of the study are presented as follows:

To assess the roles of women's participation for economic development of Bule Hora and Yabelo District.

1. To identify the backward traditional conditions which affects women participation in economic activities.

2. To identify the economic factors, that affects women participation in economic activities in the study area.

3. To explore the social factors those limit women's participation in economic activities in study area.

\subsection{Hypothesis of the study}

Several statements of supposition can be made in view of determinants and constraints of women's participation in economic activities at the study area. The following lists of hypotheses are the major ones on which the study is pivoting.

\section{Hypothesis 1}

Ho. The number of children has no effect on women's participation in economic activities.

Hypothesis 2

Ho. Affirmative action has insignificant effect on the participation of women in economic activities. 


\section{Hypothesis 3}

Ho. In average as the age of a women increases her participation in economic activities decreases.

Hypothesis 4

Ho. Education of women negatively affects their participation in economic activities.

Hypothesis 5

Ho. Credit service has significant impact on the participation of women in economic activities at the study area.

Hypothesis 6

Ho. Marital has insignificant impact on the participation of women in economic activities.

Hypothesis 7

Ho. In average as a woman increases her willingness in team work her probability of increasing in economic activities is high.

\section{Hypothesis 8}

Ho. Business oriented training for women has significant impact on the participation of women in economic activities at the study area.

Hypothesis 9

Ho. Government policy has significant impact on the participation of women in economic activities at the study area.

\section{IV.Research Methodology \\ 4.1. Background of Study Area}

This study is conduct in Bule Hora district from West Guji Zone and Yabelo District from Borene zone, Oromiya Regional State, Southern Ethiopia. The two districts are selected due to the fact that, among the districts found in both zones two of them are different from others districts. First, economic institutions (modern economic sector) side there are different in type and number of private institutions, government institution, NGO, businessmen, business activities are found in the both two districts. As a result the researcher forecast that, the necessary and sufficient information/ data regarding to economic activities and non-economic activities was available. Second, the researcher estimated that more economic problems like more unemployed and underemployment, exploitative of labor force are found largely in the selected districts. Third, the since the capital to town of the two zones are found in the selected all directive they represent their zone. Fourth, both are the populous from their respective zone (CSA, 2017); and the all structure the population size with their own behavior and wasavailable regarding to women either participation in the economic or non-economic activities. Thus, researcher selected both districts purposively.

\section{Yabelo District}

Yabello town is located at distance of $570 \mathrm{~km}$ from Finfine /Addis Ababa the capital of the country at the southern direction, in Borena zone, Oromia Regional state. Borena zone, more of its areas were settled by pastoralist community which depend on rearing of livestock and the agricultural community in ,badda $/$ highland areas depend on farming and mixed forming based on rain feed agricultural. Yabelo district is one of the districts of former and recently established Borena zone.

Regarding population size of the district, Yabelo district had a total population size of 102,165 of which 51,418 were males and the left 50,747 people were females; and from the total urban population size of 17,497 population sizes 9,398 people were males and the left 8,099 people were females. And from the total urban population size of population sizes people were males and the left people were females. And from the total rural population size 84,668 the male were 42,020 and 42,648 were females (CSA, 2007).

\section{Bule Hora District}

Bule Hora ${ }^{1}$ district is located in the center part of West Guji Zone. Bule Hora district is one of former district in the zone; and currently, it is organized by 43 rural gandas/aradas (farmers associations, sub-district administration unit) and 5 urban ardas (urban dwellers associations) and 3 town administration and the district has a total area of about $4600 \mathrm{KM}^{2}$ (Zone Finance and Economic Office, 2009).

Bule Hora district is relatively the most populous district of West Guji zone. It has a crude population density of 58 persons per $\mathrm{km} 2$. The average family size in rural area was 5.6, while in urban 5.7. In general, the total average family size of the district was 5.6. Regarding wider age group, about $51 \%$ of the total population of the district was young (below 15 years old), while economically active population (15-64) was about 46\%. Population of age above 64 years was about $3 \%$ of the total population of the district. Regarding population size of the district, Bule Hora district had a total population size of 264,489 of which 133,730 were males and the left 130,759 people were females; and from the total urban population size of 35,245 population sizes 18,211people were males and the left 17,034 people were females. Also, from the total rural population size 229,244 people the total 115,519

\footnotetext{
${ }^{1}$. "Bule" means residing whereas "Hora" means the state of being prosperous. The combination of the two terms meant the residence (place) of prosperity. The name Bule Hora was first coined in the town by the owner of a private clinic called Mr. Oda Wako he was formerly a health official at Yirgalem hospital but later came to his birth town and opened his clinic naming „Bule Hora Clinic ${ }^{\text {ce }}$ in the center of the town in 1992.
} 
people were males and 113,725 were females (CSA, 2007).

Fig. 3.1. Physical map of the study area (Bule Hora Districts and Yabelo Districts)

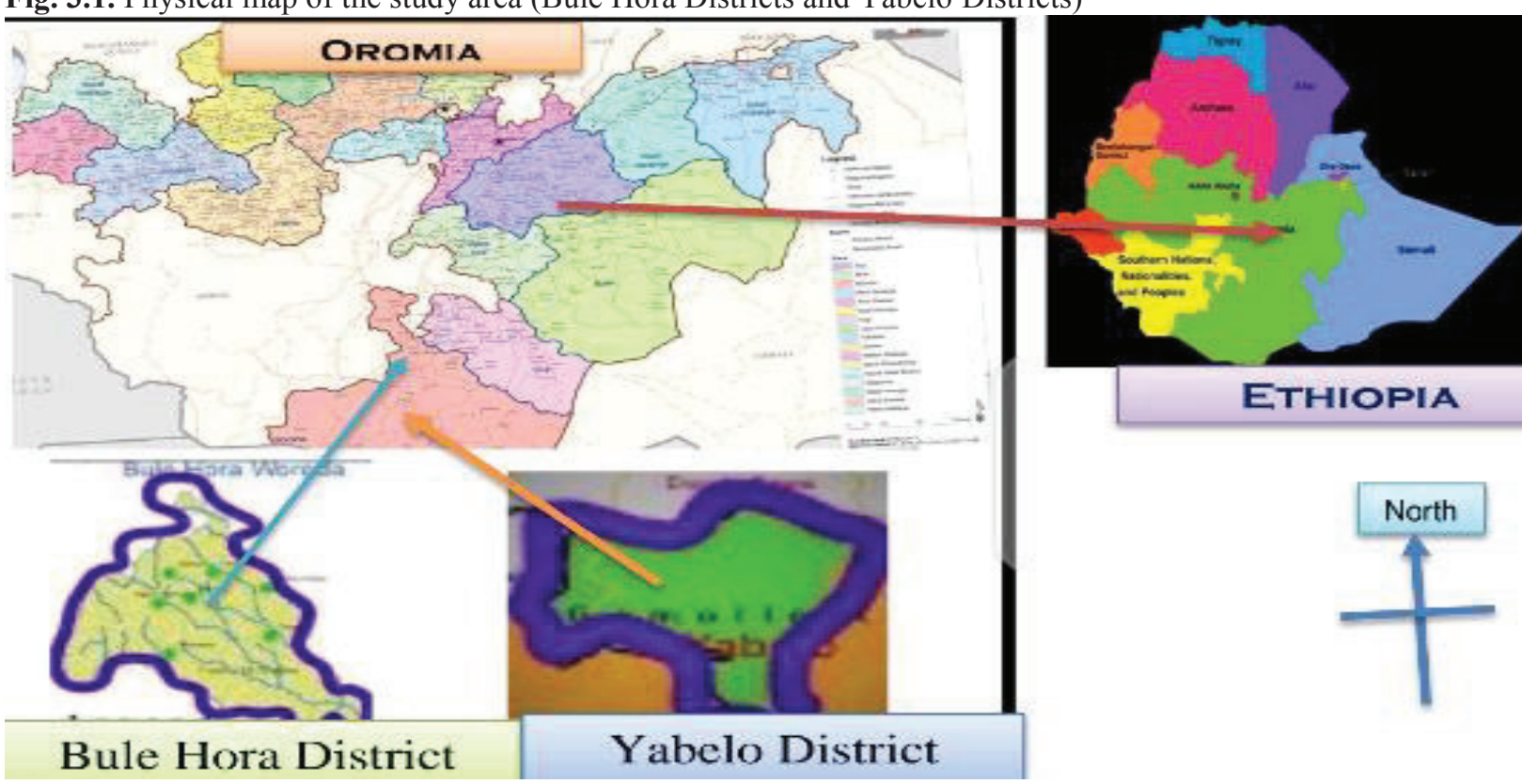

Source: www.gps.

\subsection{Sources and Methods of Data Collection}

The researcher was used both primary and secondary sources of data; mainly primary data which was collected from different primary sources which include research tools such as questionnaire, interview, and focus group discussion. To collect the secondary sources government's annual reports, reports of the central statistical agency, magazines, and other any directly related to the title of the researcher at study area was used. This implies there were sufficient data during the conducting the research.

\subsection{Sampling Technique and Sampling Size}

The use multi-stage or mixed techniques, to determine the sample size. That starting from, stratifying, population into four of the two selected districts: First Population of Bule District who live in the town, second ,Population of Bule District who live in rural area, third, Population of Yabelo District who live in the town, and fourth, Population of Yabelo District who live in rural area to until selecting respondents randomly. Let's explain the steps one by one:

First step: Selection of two districts among those found in Borena Zone West Guji Zone

The researcher selects Bule Hora district from West Guji Zone and Yabelo District from Borene zone purposively. The two districts are selected due the fact that, among all the districts found in both zones two of them are different from others district. For this the reasons are: first, the capital towns of the two zones are found in the selected distinct. Second, as explained under sub- topic of background of the study, both districts are the most populous from their respective zone (CSA, 2017); and the all structure the population size with their own behavior and wasavailable regarding to women participation either an economic or non-economic activities. Therefore, depending upon the two facts explained above the researcher Bule Hora District and Yabelo District from Borene zone purposively due to the following reasons: first, from economic institutions (modern economic sectors) side, the researcher forecast that there are different in type and numbers of private institutions, government institution, NGO, businessmen, business activities are found in the both two districts. As a result the researcher forecast that, the necessary and sufficient information/ data regarding to economic activities and non-economic activities wasbe available. Second, the researcher estimate that more economic problems like more unemployed and underemployment, exploitative of labor force, practice of the non-economic activities, found largely in the selected districts.

Second step: Determination of the sample size

The researcher uses the proportionate stratified probability sampling technique from the selected district. Depending up on the CSA, 2007 the selected district total population size is estimated to 502,141 total people of Bule Hora district And Yabalo District including both working age group and non-working age peoples group; among these 248,576 peoples are females and the left 253,565 people are is males, for detail see appendix II. And active age group (about $55 \%$ of the population female) wasbe become the population (N) e. $0.55 \times 248,576=136585$. Then, sample size can be determined b y u s i n g 95\% level of confidence, $5 \%$ degree of variability and margin 
of error (e) (Yemane, 1967 cited in Bahabelom, 2010).

$$
\begin{aligned}
& \mathrm{n}=\frac{N}{1+N\left(e^{2}\right)} \\
& \mathrm{n}=\frac{136585}{1+136585(0.05)^{2}}
\end{aligned}
$$

$n=399$

Where, n: sample size, N: population size e: level of accuracy

A total of 399 respondent's was selected from the districts.

Third Step: Dividing the Population of the Two Districts into Urban and Rural with their estimated population size

Table 3.1.The Estimated Working Age Number of Population at the Study Area

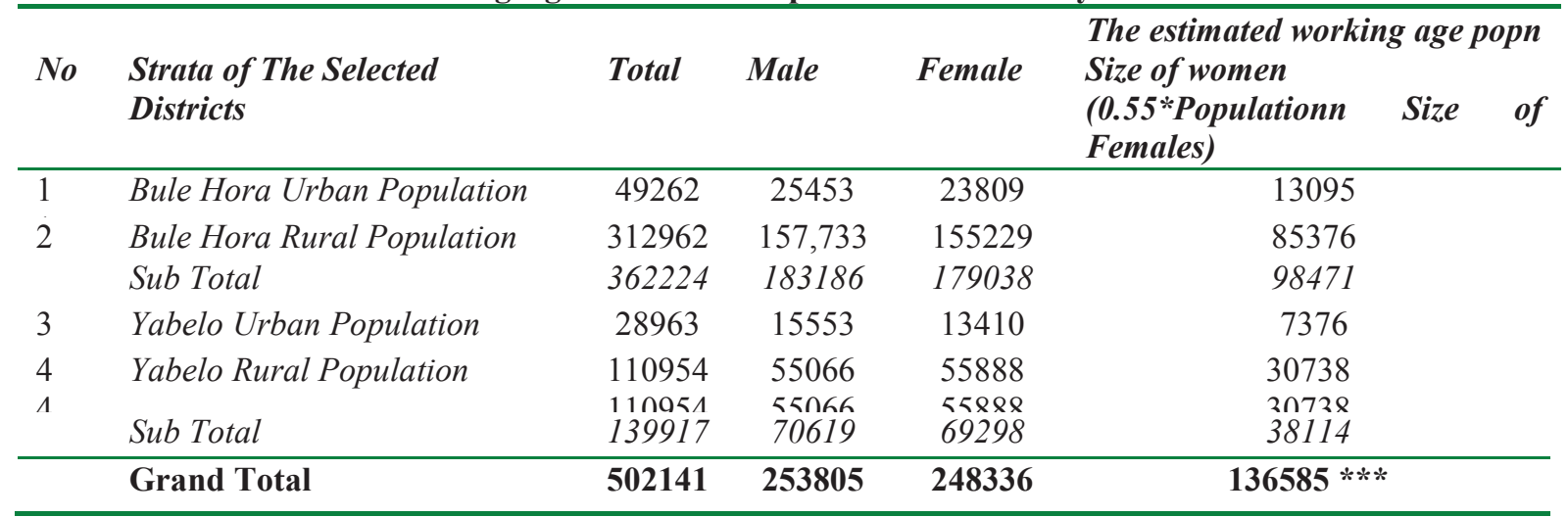

Source: estimated by the researchers based CSA, 2007 population data at the study area, 2018

*** shows size of the pop

Fourth step: Determination of the Number respondents' proportion to their population

Table 3.2. Determination of the Number Respondent's In the Sub Division of the Study Area

\begin{tabular}{llll}
\hline No. & $\begin{array}{l}\text { Strata of the Selected } \\
\text { Districts }\end{array}$ & Population Size of Working Age & Proportion \\
\hline 1 & Bule Hora District & 98,471 & 287 \\
2 & Yabelo District & 38,114 & 112 \\
\hline & Total & $\mathbf{1 3 6 5 8 4 . 8}$ & 399 \\
\hline
\end{tabular}

Source: Estimated by researchers depend on the number of households

Fifth step: Selecting the ganda (lower administration units of each district) and respondents from each ganda. The last step in the sampling technique was selecting gandas (lower administration units of each district) randomly both in rural urban areas. Finally, the researcher was select each respondent from each ganda by using simple random method. Additionally, the researcher was pick up respondents for focus group discussion purposively depending on the availability of data, the concerning body like Children and Female Affairs Officer and others directly concerns with to title of the research.

\subsection{Method of Data Analysis}

Data collected data was analyzed by using both descriptive method and econometrics approach. In the descriptive analysis, the researcher used descriptive statistics. In the second part econometric issues, more specifically, Logit model was used adopt. Also, the independent variables those significant and insignificant independent variables would be as identified. Additionally, the correlation among independent variables was determined by using recent STATA software.

\subsubsection{Description of Variables}

\section{A. Independent Variables}

The researcher identifies about eight independent variables. These are:

1. Age of women: is measured as continuous variable and expected to affect the willingness to pay decision of women for economic activities negatively, this is it is expected as level of age of women increase the participation of women on economic activity is decrease due to their ability of work decrease.

2. Number of children: Number of children refers to the numbers of child with the age of bellow fifteen year. It is expected that if the number of children increases the participation of women in economic activity decrease due to their home work to serve their children. It is categorical variable or continuous variable.

3. Educational level of women: It was taken as continuous variable in terms of years of schooling. And it is expected that because of as education level is increase the number of non-participants decrease and education is promoting women in economic activities. 
4. Marital status of women: is a situation that an individual is being married or single. It is expected that if the women have husband her economic participation affects negatively because she may be dependent on her husband income otherwise positively affect. Thus, if they are married it was take 1 otherwise 0 .

5. Affirmative action: is a plan to equalize employment opportunities and contracting opportunities for the minority and women. If affirmative action increases the women participation in economic activity increase, so affirmative action affects women economic participation positively. If affirmative action is applied it was take 1 otherwise 0 .

6. Training given for women: it refers to an organized activity aimed at imparting information and instruction to improve the recipient's performance or to help attain a required level knowledge or skill; and expected to affect women participation positively. If training for the women is given on how to participate and success in economic activities it was take 1 otherwise 0.

7. Lack of interest to work in group (corporation): women are fearful of corporation and they are not well aware of the benefit of working together. Working in corporation, especially for women can make their roles visible and it also increase their confidence. If they work in group it was takes 1 otherwise 0.

8. Availability of credit: It was take a value of 1 for those get credit and 0 otherwise

B. Dependent Variable: participation of women in economic activities or not. The term economic activity is the more complex concept, which generally includes different types of production activities, exchange (trade and business activities), and consumption. To simplify the term consider the following diagram:

Fig 3.2. Classification of economic activities in relation to the System of National Accounts

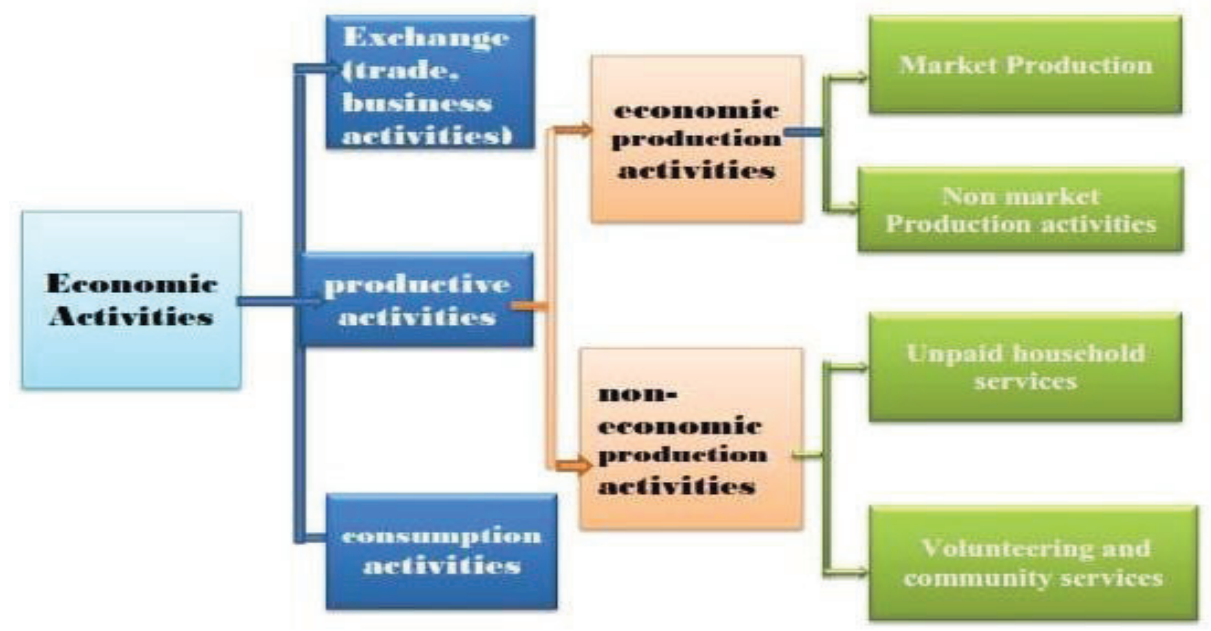

Source: Designed by the researcher by combing the concept of economic activities explaine

The economic production, covers all market production and certain types of non-market production (principally the production of goods for own use). It includes forms of work in both the formal and the informal sector, as well as forms of work inside and outside family settings. And non-economic production usually involves activities leading to the production of unpaid domestic and personal services. The noneconomic activities ${ }^{\text {ee }}$ include: unpaid household services, that is, the production of domestic and personal services by a household member for consumption within their own household, commonly called „household chores ${ }^{\text {ee }}$. Household chores include services rendered by and for household members, such as preparing and serving meals; mending, washing and ironing clothes; shopping; caring for siblings and sick/disabled household members; cleaning and maintaining the household dwelling; repairing household durables, among others (CSA, 2015).

Even though, consumption is a component of economic activities, the researcher wasnot use it in the determination of the dependent variable, because consumption expenditure exist at any social structure level and it affects saving and investment of households. In the conducting the research, from the sub-division of economic activities, the researcher wasfocus on both economic.

\subsubsection{Model Specification}

The dependent variable is women participation in economic activity which has two outcomes; either participate or not participate in the economic activities. Arbitrary values 1 and 0 can be assigning for participate or not participate respectively. For a dummy dependent variable, binary responses models such as logit and probit models are best suit for analysis. As Hosmer and Lemeshew (1989) pointed out, a logistic distribution (logit) has advantages over the other in the analysis of dichotomous outcomes variable in that it is an extremely flexible and easily usable model from mathematical point of view and results in a meaningful interpretation. The researchers wasemployee the logit model for its simplicity in this research (Gujarat, 2009).

The dependent variable of a logit model takes a binary response. That means $\mathrm{Yi}=1$ if a woman is participate and 0 if $\mathrm{Yi}=0$ if a women is not participate. 
The form of the Logit model is shown as follows.

$Y=\alpha+\beta_{1} X_{1}+\beta_{2} X_{2}+\beta_{3} X_{3}+\ldots+\beta_{k} X_{k}+\varepsilon$

Where,

$\mathrm{Y}=$ Probability of a woman being is participate or non -participate

$\alpha=$ Intercept (constant) term

$\beta_{\mathrm{i}}=$ Coefficients of the predictors estimated using the maximum likelihood method

$\mathrm{X}_{\mathrm{i}}=$ Predictors (independent variables)

$\varepsilon=$ Random effect (error term)

Let's suppose that the response variable * $y$, captures a true status of the woman either as participate or nonparticipate so we can estimate the regression equation as follows is not observable and is a latent variable. We can observe $Y i$ as a dummy variable that takes the value 1 if $* y \quad 0$ and takes the value 0 otherwise.

is distribution depends on the vector of predictors $X$, so that the vector of parameters and error terms are denoted with . The error terms entail the common assumption of zero mean and underlying distribution of the error terms is logistic.

Aggregating the value yields.

$* \mathrm{y}=\alpha+\sum_{k=1}^{k} \beta k X k+\varepsilon$

In practice $* y$ is unobserved, and $\varepsilon$ is symmetrically distributed with zero mean and has cumulative distribution function $(\mathrm{CDF})$ defined as $\mathrm{F}(\varepsilon)$. What we observe is a dummy variable

$\mathrm{y}$, a realization of a binomial process defined by

$\mathrm{y}=\left\{\begin{array}{l}1, \text { if } y>0 \\ 0 \text { otherwise }\end{array}\right.$

From equation (1) leaving the constant term and rewriting the model yields

$\operatorname{Prob}(\mathrm{Y}=1)=\operatorname{Prob}\left(\sum_{k=1}^{k} \beta k X k+\varepsilon>0\right)$

$$
\begin{aligned}
=\operatorname{Prob} & \left(\varepsilon^{>}-\sum_{k=1}^{k} \beta k X k\right) \\
& =1-F\left(-\sum_{k=1}^{k} \beta k X k\right)
\end{aligned}
$$

The logit model usually takes two forms. It may be expressed in terms of logit or in terms of event probability. When expressed in logit form, the model is specified as

$\log \left\lfloor\frac{p(y-1)}{1-p(y=1)}\right\rfloor_{=} \sum_{k=1}^{k} \beta k X k$

Using equation ' 4 ' and ' 5 ' can be transformed into a specification of the logit model of event probability by replacing the general $\mathrm{CDF}, \mathrm{F}$, with a specific $\mathrm{CDF}$, L representing the Logistic distribution

$\operatorname{Prob}(\mathrm{y}=1)=1-\mathrm{L}\left(\sum_{k=1}^{k} \beta k X k\right)_{=} L\left(\sum_{k=1}^{k} \beta k X k\right)$

$=\frac{e^{\sum_{k=1}^{k} \beta k X k}}{1+e^{\sum_{k=1}^{k} \beta k X k}}$

6

The above equation was represent the probability of an event occurring. For a non-event, the probability is just 1 minus the event probability.

$$
\begin{aligned}
& \operatorname{Prob}(\mathrm{y}=0)=\left(\sum_{k=1}^{k} \beta k X k\right)=\mathrm{L}\left(\sum_{k=1}^{k} \beta k X k\right) \\
& \frac{e^{-\sum_{k=1}^{k} \beta k X k}}{=1+e^{-\sum_{k=1}^{k} \beta k X k}} \\
& \ldots \ldots \ldots \ldots \ldots \ldots \ldots \ldots \ldots \ldots \ldots \ldots \ldots \ldots
\end{aligned}
$$

Also since the above equation $\mathbf{z i}=\boldsymbol{\beta 0}+\boldsymbol{\beta} 1 \mathbf{x} \mathbf{1}+\boldsymbol{\beta 2} \mathbf{2} \mathbf{2}+\boldsymbol{\beta 3} \times \mathbf{3}+\ldots+\boldsymbol{\beta i x i}+\mathbf{E i}$ from the above model let us substitute zi with dp(dummy of participation) as the dependent variable.

Where $\mathrm{dp}=$ dummy of poverty, Ei is error term, $\beta 0$ is constant and $\beta$ 's are coefficients.

The researcher specify y the model as follow through the relationship between dependent and independent variables.

$Y=f(a g w, n c h l, e d u l$, mars, afc, tra, avc, incl, wkgp)

Where

$Y=$ women's participation in economic activities agw= age of women

$n c h l=$ number of children of women mars = marital status of women afc $=$ affirmative action

tra $=$ training level of women edul=education level of human avc= availability of credit

$w k g p=$ interest of women to work in group (corporation)

\subsubsection{Tests of the Model}

\section{A. Multi-collinearity test}

Multi-collinearity is the violation of OLS assumption. It is occurred when there is linear relationship between the explanatory variable. In practice, there is no perfect multi-collinearity, but the problem is tested by testing VIF (variance inflection factor). It is calculating using the formula 


$$
\mathrm{VIF}=\frac{1}{1-R^{2}}
$$

If the mean value VIF is greater than 10, there is a problem of multi colinarity and vice versa (Gujriti, 2009).

B. Heteroscedasticity

Heteroscedasticity is another violation of OLS assumption. It is the valuation of the assumption of homoscidacity that implies no constant of the error term. This problem can be tested by comparing chi square and critical value chosen at the level of significance. If the pro $>$ chi square is higher than critical value chosen at level of significance there is no heteroscedasticity and vice versa, ibid.

\section{Data analysis and Interpretations}

\subsection{Descriptive Analysis}

This chapter deals with presentation, interpretation and analysis of the collected data. Accordingly, the collected data in line with each objective of the study is presented, interpreted and analyzed under its respective session. The chapter has two broad parts which include: Descriptive Analysis and econometric analysis of the determinants of women participation in economic activities results.

The results of the study were explained by descriptive methodThis section of the study mainly concerned with a descriptive analysis of the result of the sample survey and interpretation of analytical findings. The descriptive statistics, such as tables and percentages was used to identify the determinants of women participation of women economic activities in the study area.

\subsubsection{Demographic Structure of the Respondents}

Since this part is the discussion of the responses from the questioners collected from women, it begins with demographic features of the respondents.

\section{i. $\quad$ Response Rate of Respondents}

After submitting the support letter to the concerning the government office, Women, Youth and Children Office in order to cooperate in providing the necessary data. Accordingly, 8 officials and 5 officials were interviewed from rural and urban officials of Women, Youth and Children Office Bule hora Districts and Yabelo Districts respectively. The detail of this the respondents was in the table 4.1.as below.

Table 4.1. Response Rate of Respondents

\begin{tabular}{llllll}
\hline No. & Districts & $\begin{array}{l}\text { Data Collection } \\
\text { tools }\end{array}$ & $\begin{array}{l}\text { No. of respondents } \\
\text { planned }\end{array}$ & $\begin{array}{l}\text { No. } \\
\text { answered }\end{array}$ & $\begin{array}{l}\text { of } \\
\text { rate }\end{array}$ \\
\hline 1 & Bule Hora & Questionnaires & 287 & 276 & $96 \%$ \\
& & Interview & 8 & 8 & 100 \\
2 & Yabelo & Questionnaires & 112 & 98 & $87.5 \%$ \\
& & Interview & 5 & 3 & $60 \%$ \\
\hline
\end{tabular}

Source: Own Survey, 2019

Thus based on the prepared schedule 399 questionnaires are distributed to the participants and from these 276 respondents from Bule Hora District, and 112 respondents from Yabelo Districts; while 25 questionnaires were did not return back from respondents. Due to this reason, $93.7 \%$ of the distributed questioners are collected, almost all respondent express their view properly and few open ended questions are left blank without giving their reply. In this data collection totally 11 officials was interview from these 8 Bule Hora Districts officials and 3 of interviewee were from Yabelo Districts. Due to this reason, $81.25 \%$ of the distributed questioners are collected, almost all respondent express their view properly and few open ended questions are left blank without giving their reply. 
Table 4.2. Women Association in Bule Hora Districts

\begin{tabular}{lllllll}
\hline No. & Name of Group & $\begin{array}{l}\text { No. } \\
\text { women }\end{array}$ & $\begin{array}{l}\text { Starting } \\
\text { year }\end{array}$ & $\begin{array}{l}\text { Payment } \\
\text { year month }\end{array}$ & $\begin{array}{l}\text { Capital } \\
\text { size }\end{array}$ & $\begin{array}{l}\text { The conditions they } \\
\text { help each other }\end{array}$ \\
\hline 1 & Burka Gemeda & 70 & 2008 & 15 & 40,000 & During sadness \\
2 & Abdi Boru & 30 & 2006 & 50 & 21,000 & During sadness \\
3 & Hora & 40 & 2000 & 10 & 14,400 & During sadness \\
4 & Mek Goro Gudina & 53 & 2009 & 20 & 13,503 & During sadness \\
5 & Hingudane & 12 & 2005 & 10 & 1,360 & During sadness \\
6 & Madagari & 42 & & 20 & 5,600 & During sadness \\
7 & Nijarana & 266 & & 20 & 7,543 & During sadness \\
8 & Ehetmamachochi & 29 & & 20 & 20,880 & During sadness \\
9 & Kuteba & 30 & 1986 & 10 & 26,880 & During sadness \\
10 & Selam Mederaja & & & & 30,000 & During sadness \\
11 & Beyenech Mederaja & 50 & 1987 & 20 & 15,960 & Marring sadness \\
12 & Bulchinsa Megala & 43 & 2010 & 30 & & delivery \\
& & & & 16,000 & During sadness \\
13 & Selam & 24 & 2009 & 20 & 12,000 & During sadness \\
14 & Yemariam & 25 & 1986 & 20 & 13,600 & During sadness, \\
15 & Wolda Hojetota & 40 & 2010 & 20 & & delivery \\
& B/M/BH & & & & & and marriage \\
\hline
\end{tabular}

Source: Gender Office and Children Office of Bule Hora Town, 2019

45,000

\section{CAPITAL SIZE}

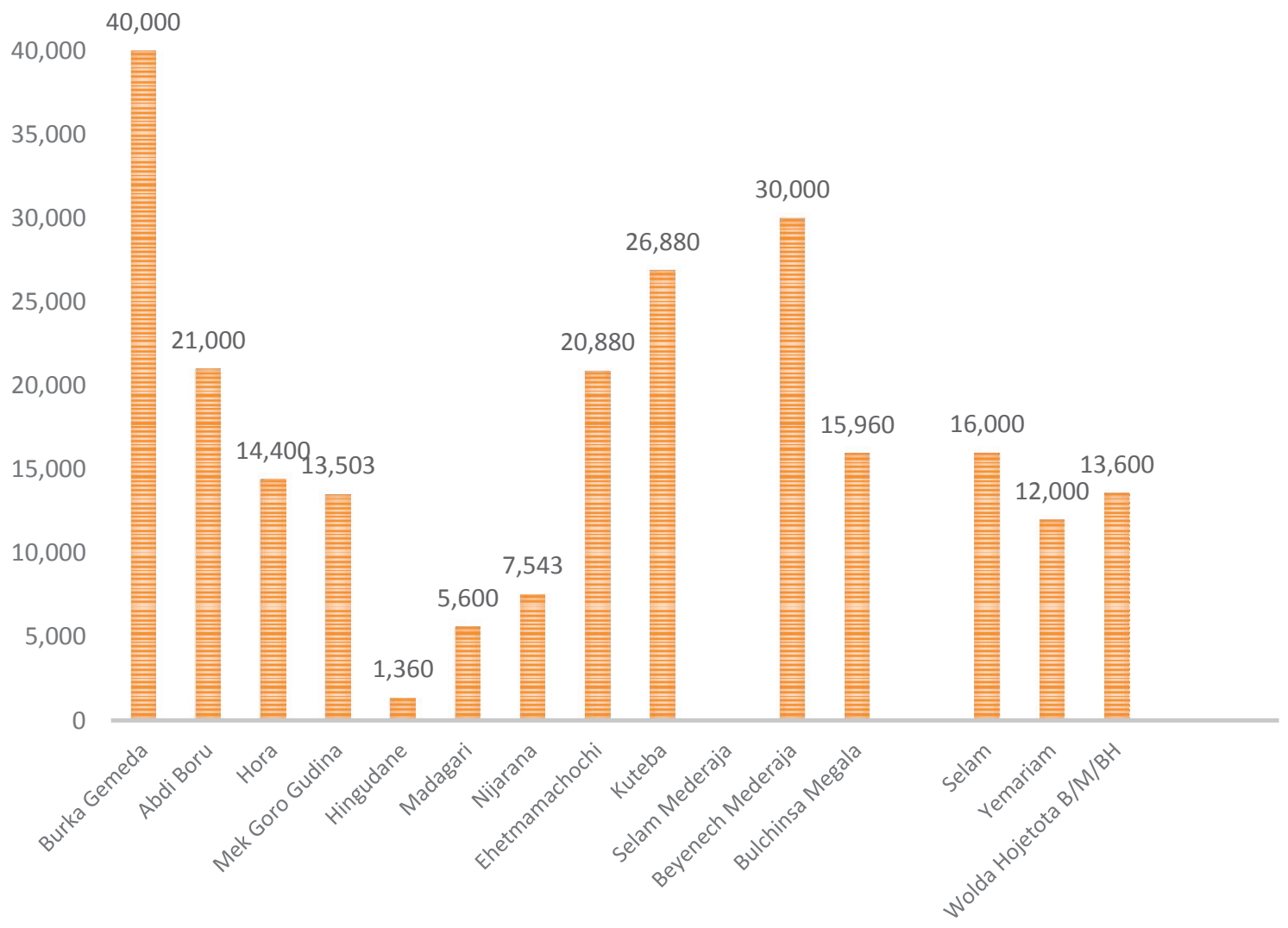

Fig. 4.1. Women Association in Bule Hora Districts

ii. $\quad$ Age and sex of Respondent

As shown in the following table the sex of the respondents who participate in responding, or filling the questionnaire were female. But, in interview and focus group discussion they are both females and males. 
Table 4.3. Sex Structure of the Respondents

\begin{tabular}{lllll}
\hline Sex & Respondents & & & \\
\cline { 2 - 5 } Female & 236 & In percentage & Non participants & In percentage \\
Total & 236 & $63 \%$ & 138 & $37 \%$ \\
\hline
\end{tabular}

Source: Own Survey, 2019

The above table shows that all of the respondents were female, out of which $63 \%$ are participants and the remaining $37 \%$ are non-participants.

The following table shows that 77.56 percent of the participants (almost most of the respondents) were in the age between 31 and 64. This represents the productive age of the respondents. From the non-participants, 57.9\% were in the age between 18 and 30 due to lack of different facilities to participate in economic activities. As it depicted in table 4.4 below, as age level increases the participation of women in economic activities decrease due to their ability to work decrease.

Table 4.4. Age of the Respondents

\begin{tabular}{llllc}
\hline Age & Respondents & & & \\
\cline { 2 - 5 } & Participants & In percentage & Non participants & In percentage \\
$18-30$ & 67 & $42.1 \%$ & 92 & $57.9 \%$ \\
$31-64$ & 159 & $77.56 \%$ & 46 & $22.44 \%$ \\
$>64$ & 10 & $100 \%$ & 0 & $0 \%$ \\
Total & 236 & 100 & 138 & 100 \\
\hline
\end{tabular}

Source: Own Survey, 2019

iii. Number of Children of the Respondents

As explained in table 4.5.below, from the respondents who had two, one or no child, most of them $(82.83 \%)$ of the respondents were participated in economic activities while $17.17 \%$ respondents were non-participants at the study area. On the other hand, from non-participants of women in economic activities most of the respondents $(57 \%)$ had more than four children whose their age is less than 18 years. Women in the richest households remain almost twice as likely to use modern family planning as the poorest women (51.1 per cent and 27.2 per cent, respectively) (UNICEF, 2017). In general, as the number of children (who are non-labor force) of women's the participation of women's in economic activities decreases.

Table 4.5. Number of Children of the Respondents

\begin{tabular}{lllll}
\hline Number of Children of respondents & Respondents & & & \\
\cline { 2 - 5 } & Participants & In percentage & Non participants & In percentage \\
No, one and two children & 82 & $82.83 \%$ & 17 & $17.17 \%$ \\
2-4 years old & 96 & $68.1 \%$ & 45 & $31.9 \%$ \\
Greater than 4 years & 58 & $43 \%$ & 77 & $57 \%$ \\
Total & 236 & & 138 & \\
\hline
\end{tabular}

Source: Own Survey, 2019

iv. Marital Status of the Respondents

As the collected data indicates that, from women's participants in economic activities about 55.5\% of them were single (most of them unmarried) while 105 of respondents $(44.5 \%)$ were no - single (married) women. On the other hand as explained in the table 4.6 from women's who were non-participants in economic activities, about 93 of respondents of women $(67.4 \%$ ) were non-single (married) and 45 of respondents (32.6\%) were single(unmarried) women.

This shows that the probability of women's participation in the economic activities were decreasing as they married. Table 4.6. Marital Status of the Respondents

\begin{tabular}{lllll}
\hline Marital & Respondents & & & \\
\cline { 2 - 5 } status & Participants & In percentage & Non participants & In percentage \\
Single & 131 & $55.5 \%$ & 45 & $32.6 \%$ \\
Non-single & 105 & $44.5 \%$ & 93 & $67.4 \%$ \\
Total & 236 & & 138 & \\
\hline
\end{tabular}

Source: Own Survey, 2019

\subsection{Determinants of Women's Participation in Economic Activities}

The participation of women in economic activities is expected to improve the long term economic and social security of its house hold through affirmative action, training and credit services. Many studies indicate that the participation of women in economic activities has appositive effect on the welfare of the society.

\section{a. Affirmative Action Status of the Respondents}

According to the 26.6 result which is explained in table 4.7 .below, from the participants $37 \%$ of the respondents didn't get affirmative action and $73 \%$ of the respondents enjoy affirmative action. On the other hand from the non- 
participants $64.4 \%$ of the respondents didn't get affirmative action and $26.6 \%$ of the respondents get affirmative action. This proves that as women get incentives, motivation (affirmative action) the probability of women's participation in economic activities increases.

Table 4.7.Affirmative Action of the Respondents

\begin{tabular}{lllll}
\hline Affirmative & \multicolumn{3}{l}{ Respondents } & \\
\cline { 2 - 5 } Actions & Participants & In percentage & Non participants & In percentage \\
Yes & 199 & $73 \%$ & 74 & $26.6 \%$ \\
No & 37 & $36.6 \%$ & 64 & $63.4 \%$ \\
Total & $\mathbf{2 3 6}$ & & $\mathbf{1 3 8}$ & \\
\hline
\end{tabular}

Source: Own survey, 2019

Training Level of the Respondents

The result of the finding (as explained in table 4.8), demonstrates that the majority of the respondents $(82.6 \%)$ from the economic participants got business training from the government, or NGOs or any other stakeholders and $17.4 \%$ of the respondents didn't get business training from the government, or NGOs or other stakeholders. On the other hand, from the non-participants, $44.9 \%$ of the respondents got training and $55.1 \%$ of the participants didn't get business training from the government, NGOS or any other agent.

Table 4.8. Training Level of the Respondents

\begin{tabular}{lllll}
\hline Training & \multicolumn{5}{l}{ Respondents } & & \\
\cline { 2 - 5 } & \multicolumn{5}{l}{ Participants } & In percentage & Non participants & In percentage \\
Yes & 195 & $82.6 \%$ & 62 & $44.9 \%$ \\
No & 41 & $17.4 \%$ & 76 & $55.1 \%$ \\
Total & 236 & & 138 & \\
\hline
\end{tabular}

Source: own survey, 2019

Credit Service of the Respondents

The credit service status profile of the respondent demonstrates that, about $85 \%$ of women who participated in the economic activities was got credit services and about $15 \%$ of whom didn't get credit services. One the other hand, about $9.4 \%$ of women who didn't participate in the economic activities get credit services and $90.6 \%$ of women who didn't participate in the economic activities didn't get credit services.

Table 4.9. Credit Service of the Respondents

\begin{tabular}{|c|c|c|c|c|}
\hline Credit Service & $\begin{array}{l}\text { Participation in Economic } \\
\text { Activities }\end{array}$ & Percentage & $\begin{array}{l}\text { Non Participation in the } \\
\text { economic activities }\end{array}$ & Percentage \\
\hline Yes & 200 & $85 \%$ & & $9.4 \%$ \\
\hline No & 36 & $15 \%$ & 125 & $90.6 \%$ \\
\hline Total & 236 & $100 \%$ & 138 & $100 \%$ \\
\hline
\end{tabular}

Source: own survey, 2019

\subsection{Constraints of Women's Participation in Economic Activities}

Women face different problems that limit them from effective participation on economic activities. Some of these are financial, social, natural and other problems. Additionally some these constraints were explained by previous researchers for instance Gashaw (2015. In rural and urban of the study area, the qualitative information from group interviews and focus group discussion result can be explained as follow on the determinants or constraints of women's participation in economic activities.

Lack of business know how: Women involve in various economic activities especially in marketing process and trading activities, but they lack business know how i.e how to run business and cost benefit analysis.

Dependency of family on women: culturally in some families some members are dependent on the earning of women. In some cases husbands remain dependent on their wife's' income, such as dependency of family members on women makes their roles invisible unrecognized. However, women are continued to play their roles in various economic activities.

Women's Dependency on Men's income: despite the existence of families' dependency on women in some case there is also women's dependency on men's income. This is due to the influence exerted by their husbands. If this is developed, they did not give decision by their own in their overall life. In this case dependency of women can bring lack of decision making power and this make the roles of women unrecognized.

Financial constraint (Lack of initial capital to start their own business): Despite the high interest and motivation of women to work, lack of initial capital to start up and to run the business hinder their economic activities. Financial constraint is a substantial problem for active participation of women in the economy. It must be noted that without any initial capital nothing can be done. This problem is associated with lack of credit inefficiency of financial institutions. Lack of access to credit is a formal barrier often restricting women's ability 
to smooth consumption over time and under taken productive activities. As a result we accept that financial problem is one of the very constraints of women's participation in the economic activities in Bule Hora and Yabelo districts.

Social constraint is a problem that hinders women's effective involvement in economic activities. But in relation to other constraints, this constraint has a little influence on women's participation on economic activities.

Traditional attitude: Among the factors that make rural women not participate in economic activities most family were leaded by males (husbands) and its consequences is a limited own to productive resources, skills, finance and information, together with an inability to build resilience by diversifying their work and build up assets.

Women's lack of confidence is mainly due to the culture of the society and their inferiority assumption. In addition women are not highly committed and they lack interest to take full responsibilities and accountabilities and they are fear of challenges, especially in office positions. Despite the existence of the above mentioned barriers on women's effective roles in the economic development, they are continued to play their role in economic development. Even though different problems hinder the participation of women's in their roles in varies economic activities are significant.

On the other hand, the gender based labour divisions in households and cooperative work and social lives as neighborhood traditions were made clear through the performances. This performance showed that in Guji society, cooking food, preparation of coffee, serving food, cleaning the home, and fetching water are women's (wives') work. Working on farms and the cultivation of food crops are men's (husbands) work (Tadesse,2013).

\subsection{The Role of Women's Participation in Economic Activities to Development}

Women's participation in economic activities is critical for economic growth and development. It accelerates growth by rising productivity and promoting the efficient use of resources. Based on this assumption the respondent asserted the following roles of women's participation in economic activities on the economy.

Supporting Economic Growth and Development: Economic growth is highly related with productivity and efficient use of resources, so that women's participation in different economic activities reduces the unemployment and in turn increases the GDP of the country. In economic growth and development, women's participation in economic activities has significant impact on promoting the growth of the country.

To overcome on Absolute Poverty: Women's participation in economic activities is found to be pertinent to reduce poverty. In short, the respondents assert that women's participation in the economic activities contributes a lot to reduce poverty at all levels of communities. Women in Yabelo District, establish marro with rich women, in which the poor women provide labour, and in return receive resources needed in their households. There was a good culture which motivates women in the participation of economic activities and strength cooperative activities. Food security: women's participation in economic activities has also a significant effect on food security. That is, the respondents asserted that the participation of women in different economic activities advances the exultance of food security.

\subsection{Econometric Analysis of the Determinants of Women Participation in Economic Activities Results}

An economic model, logistic regression model, binary logistic model was used, by independent variables used in order to identify constraints and determinants of women's participation in economic activities at the study area. Binomial (or binary) logistic regression is a form of regression which is used when the dependent is a dichotomy and the independents are of any type. In our research, the dependent variable, i.e. the status of Women Participation in Economic Activities is either participation or not participation, which implies it is dichotomy; while the in independent variables include continuous variables. Therefore, the best model is binomial (or binary) logistic regression (Gujarati and Porter, 2009).

\begin{tabular}{|c|c|c|c|c|c|c|c|}
\hline \multicolumn{4}{|c|}{$\begin{array}{l}\text { Logistic regression } \\
\text { Log Iikelihood }--74.597038\end{array}$} & \multicolumn{2}{|c|}{$\begin{array}{l}\text { Number Of obs } \\
\text { LRChizC9) } \\
\text { Probid Chiz } \\
\text { Pseudo R2 }\end{array}$} & \multirow{2}{*}{$\begin{array}{c}= \\
= \\
\text { conf. }\end{array}$} & \multirow{2}{*}{$\begin{array}{r}34374 \\
0.0000 \\
0.6971 \\
\text { Interval] }\end{array}$} \\
\hline particistars & coef. & std. & $z$ & $P>1<1$ & {$[959$} & & \\
\hline 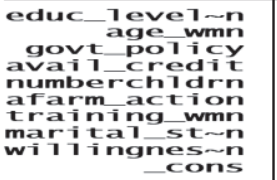 & 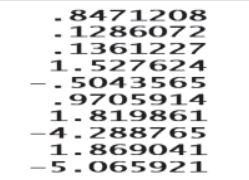 & 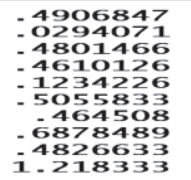 & $\begin{array}{r}1: 73 \\
4: 37 \\
0: 28 \\
3: 31 \\
-4: 09 \\
1: 92 \\
3: 92 \\
-6: 24 \\
3: 87 \\
-4.16\end{array}$ & $\begin{array}{l}\text { O: } 084 \\
0=000 \\
0=777 \\
0=001 \\
0=000 \\
0=055 \\
0=000 \\
0=000 \\
0=000\end{array}$ & $\begin{array}{r}-11146 \\
-07099 \\
-: 8049 \\
-6240 \\
=-7462 \\
-0203 \\
-5094 \\
-7936 \\
-7.45\end{array}$ & $\begin{array}{l}035 \\
704 \\
473 \\
559 \\
603 \\
336 \\
425 \\
924 \\
038\end{array}$ & 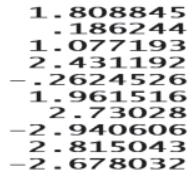 \\
\hline
\end{tabular}

Participation $=-5.06+0.85$ age +0.13 educ +0.14 policy +1.5 credit-0.5cild +0.97 afarm +1.82 train 4.29marital +1.87 team $+\square$

As explained in the table above, nine independent variables are hypothesized to have influence on women's participation in economic activities at the study area included in the model of which six are found to be statistically significant and the sign of most independent variables were as expected; that is, women's training level, age of women, number of children, marital status of women, willingness of team work of women, and credit a vailability 
were found to be significant at less than $5 \%$ probability level. Examination of the above logit model estimates demonstrates that, the variables that are positively educational level of women and training given for women correlated with the probability of being participating in economic activities; while the variables that are negatively correlated with the probability of being participating in economic activities are number of children and marital status of women.

Additionally, we can calculate t-statistics to in order to check the significances of each independent variable. For instance, it can be calculated for the number of children in order to check its significances status in the binary logistic model as below:

$$
t^{*}=\frac{b_{1}-\beta_{1}}{s e\left(b_{1}\right)} \quad=\frac{b_{1}}{s e\left(b_{1}\right)}=\frac{-0.5043565}{0.1234226}
$$

$$
|-4.09|=\underline{4.09}
$$

The value of the t-statistic that corresponds to the $5 \%$ (commonly used) significance level is 1.96 and $4.09>1.96$, so we reject the null hypothesis. That means the estimate is significantly different from zero at 5\% significant level. Thus, we reject the null hypothesis. The same is true for others independent variables also.

\subsubsection{Interpretation of Odds Ratio in the model}

In this study, dependent denoted as the participation of women in economic activities or non-participation of women in economic activities determined by various independent variables. In the other words, odds of the model tell by what factor the dependent variable change does whenever a unit change occurs in an independent variable (Gujarati and Porter, 2009). OR ${ }^{1}$ is the Log value of odds and is always positive. In this particular study it is found out that the odds ratio, the ratio of the probability of being participant to the probability of non-non participant. The detail of the model result is as follow (by using STATA Software):

Logistic regression
Log Tike1ihood = -74.597038

Let's interpret the OR results in the model one by one:

i. Age of Women: Age of women is measured as continuous variable and the decision of women for economic activities positively, this is as level of age of women increase the participation of women on economic activity is increase due to their ability of work increase. Additionally, as explained in the above table, in the result of the model the age of women is significant. This means that age has significant effect on participation of women in economic activities in the study area. It interpretation is as the age of women increases by one year the model estimates the probability of women participation in economic activities increases by 1.14 times than before.

ii. Number of Children: Number of children refers to the numbers of child with the age of bellow fifteen years according to ILO criteria; and it was continuous variable in this study which was measured by the number. The number of children is significant at less than $5 \%$ probability level, so we reject the null hypothesis is that number of children has not effect on women economic participation. It is interpreted as the number of children increases by one child, the model estimates the participation is 0.6 times as likely to dis-occur among the respondents in the study population.

iii. Women's Educational Level: It was be taken as dummy variable; i.e. educated or not. Even though educational status of women has a greater importance on the interest and willing to participation in economic activities, it is insignificant at than $5 \%$ probability level.

iv. Women Access to Credit: the result of the survey states that the variable access to credit is positively related to women's participation in economic activities and significant at less than 5\% probability level. The result of the model shows that, holding other things remain constant, the probability of women's participation in economic activities was increased by 4.61 as women access to credit services. This means that since credit is a source of finance and finance in turn serves as a base for running any economic

\footnotetext{
${ }^{1}$ Odds Ratio -The odds ratio is a measure, or it approximates how much more likely (or unlikely); it is for the outcome to be present among those with independent dummy variables is equal to one than among those independent. Odd ratio in favor of participation in economic activities - the ratio of the probability that a woman participate in economic activities to the probability that she will not participate in economic activities.
} 
activity, so as women's access to credit increases the participation of women in economic activities can be stimulated.

v. Marital Status: In the model of the study, marital status of women at the study area is significant variable at less than 5\% probability level. This means that marital status has significant effect on the participation of women in economic activities in the study area. And its result can be interpreted as probability of women's participation in economic activities is decreases by 0.014 as women married.

vi. Affirmative Action: The result of the survey states that the variable, affirmative action, is positively related to the participation of women the economic activities as explained I table above, but it is insignificant variable at the study area at $5 \%$ probability level.

vii. Training Level of Women: it refers to an organized activity aimed at imparting information and instruction to improve the recipient's performance or to help attain a required level knowledge or skill; and expected to affect women participation positively. The result of the survey indicates that the variable, training level of women, is positively related to women's participation in the economic activities of the study area and significant at less than 5\%. Probability of women's participation in the economic activities of the study area increases by 6.17 as women's access to training increases. So as women's access to training, the participation of women in economic activities can be stimulated.

viii. Willingness to work in group (corporation): women are fearful of corporation and they are not well aware of the benefit of working together. Working in corporation, especially for women can make their roles visible and it also increase their confidence. The explained in the above table, at the study area willingness to work in group has significant effect on the participation of women in economic activities and significant at less than 5\%. Probability of women's participation in the economic activities of the study area increases by 6.48 a woman have willingness to work in group than unwillingness to work in group.

ix. Government policy: Women's experiences are different from men's and need to be represented in discussions that result in policy-making and implementation. Policies can be aimed at gender mainstreaming or can explicitly advance agendas for gender equality in one area of policy. Women's presence has also proven to be important in the formulation of policies on development, sustainable peace, and good governance (DAW, 2005). The result of the survey states that the variable, government policy, is insignificant variable at $5 \%$ probability level. The means, it is not a major factor in participation of women in the economic activities at study area.

\subsubsection{Robust Standard Errors}

To overcome the fearness that the error terms may not be independent and identically distributed like heteroscedasticity may be a problem, robust standard errors was Gujartati and Porter, 2009) added ( Note that, in this case, the standard errors have changed very little, but sometimes the change will be much greater. Also, Stata now reports "pseudo-likelihoods" and a Wald chi-square instead of a likelihood ratio chi-square for the model.

$\begin{array}{llll}\text { Logistic regression } & \text { Number of obs } & = & 75.86 \\ & \text { wald chi2 (9) } & = & 75.86 \\ & \text { Prob chi2 } & = & 0.0000 \\ \text { Log pseudolikelihood }=-74.597038 & \text { Pseudo R2 } & = & 0.6971\end{array}$

\begin{tabular}{|c|c|c|c|c|c|c|}
\hline particista s & Odds Ratio & $\begin{array}{l}\text { Robust } \\
\text { std. Err. }\end{array}$ & $\mathbf{z}$ & $P>|z|$ & [95\% conf. & Interva1] \\
\hline $\begin{array}{r}\text { educ_leve1 n } \\
\text { age_wmn } \\
\text { govt_policy } \\
\text { avai_credit } \\
\text { numberchldrn } \\
\text { afarm_action } \\
\text { training_wmn } \\
\text { maritalst st n } \\
\text { wijingnes n }\end{array}$ & $\begin{array}{r}2.33292 \\
1.137243 \\
1.145822 \\
4.607217 \\
.6038941 \\
2.639505 \\
6.171003 \\
.0137219 \\
6.482075\end{array}$ & $\begin{array}{l}1.150205 \\
.0346597 \\
25071067 \\
2.233416 \\
.081662 \\
1.271126 \\
2.947783 \\
.0106576 \\
2.819672\end{array}$ & $\begin{array}{r}1.72 \\
4.22 \\
0.31 \\
3.15 \\
-3.73 \\
2.02 \\
3.81 \\
-5.52 \\
4.30\end{array}$ & $\begin{array}{l}0.086 \\
0.000 \\
0.758 \\
0.002 \\
0.000 \\
0.044 \\
0.000 \\
0.000 \\
0.000\end{array}$ & $\begin{array}{l}8876262 \\
1.071301 \\
i 4812836 \\
i .781584 \\
i 632938 \\
1.027077 \\
2.419643 \\
.0029943 \\
2.76341\end{array}$ & $\begin{array}{l}6.131542 \\
1.207245 \\
2.727932 \\
1 . .91437 \\
.7871637 \\
6.783313 \\
15.73839 \\
i 0628823 \\
15.20487\end{array}$ \\
\hline
\end{tabular}

\subsubsection{Hypothesis Testing}

Each independent variable in the model was statistically tasted one by one depend on the hypothesized before. And detail its result explained in the appendix vii.

\subsubsection{Roles of Women's Participation for Economic Development}

Women's participation in economic activities is critical for economic growth and development. It accelerates growth by rising productivity and promoting the efficient use of resources. Based on this assumption the respondent asserted the following roles of women's participation in economic activities on the economy.

Promoting Growth: Economic growth is highly related with productivity and efficient use of resources, so that women's participation in different economic activities reduces the unemployment and in turn increases the GDP of the country. As table 4.10 indicates from the output of the total respondents $37 \%$ of them asserted that women's participation in economic activities has significant impact on promoting the growth of the country.

Reducing Poverty: Women's participation in economic activities is found to be pertinent to reduce poverty. The 
above table (table 4.10) indicates that $52 \%$ of the respondents assert that women's participation in the economic activities contributes a lot to reduce poverty at all levels of communities.

Food security: women's participation in economic activities has also a significant effect on food security. Table 4.10 indicates that $3 \%$ of the respondents asserted that the participation of women in different economic activities advances the exultance of food security.

\section{Conclusion, Findings and Suggestions \\ Conclusion}

An economic activity is a process of producing and or provision of goods and service in agriculture, industry, construction, trade, etc. Currently Women constitute about $50 \%$ of the population of Ethiopia. They also contribute the highest proportion of labour force in the overall economy of the country. However, the role and contribution of women in both household and national development is significantly hampered by long-established cultural, economic and institutional constraints.

This study aimed to investigate and analyze the participation of women in economic activities as well as point out factors that affect the participation of women in economic activities in Bulehora and Yabelo Districts, West Guji Zone and Borena zone respectively by employing cross sectional data which was collected in 2019 or 2011/2012 E.C. To achieve the objectives of the study mainly primary data was collected from 374 sample size from 136585 estimated number of women the two districts totally. The samples were classified in to participants and non-participants in economic activities based on whether they were participant or non-participant.

In the analysis of the collected data both descriptive and econometrics model was used. A binary logit model was specified and estimated to identify the determinants and constraints of women's participation in the economic activities. The descriptive part of the analysis shows the relationship between women's participation in economic activities and other demographic and economic characteristics of women by using table, percentage, and graphs.

Women's have different roles in economic activity like promoting growth, reducing poverty, promoting efficiency and in achieving food security's. Women's economic participation was determined by deferent factors these were affirmative action, tanning level, education and credit. Number of children less than two years old, lack of affirmative action and financial problem are the major constraints of women's economic participation in the study area.

In the analysis of the determinants of women participation in economic activities by logistic regression model via employing nine independent variables through STATA software was done. These variables were: age of women of women, number of children, women's educational level, and women access to credit, marital status of women, affirmative action given for women, training level of women, willingness to work in group (corporation) and the government policy of the country. Among these six variables were statistically significant at $5 \%$ probability level. These variables are: age of women of women, number of children, women access to credit, marital status of women, training level of women, and willingness to work in group of women from respondents.

Specifically, the result of the binary Logit Regression Model was interpreted. And it shows that as women trained on business their participation likely occur 6.2 times relative to untrained women; the participation of women in business activities decreases by 0.014 as they married relative to single one and as the number of children increases by one, the model estimates the participation is 0.6 times as likely to dis-occur among households in the study population area, and these are significant at less than $5 \%$. It is assessed that, if a women is married it is negatively correlated with the probability being participant in economies activities. And its result was probability of women's participation in economic activities is decreases by 0.014 as women married.

Addition to the above, the gender based labor divisions was practiced at the study are: a given family the households males (husbands) participate on the working farm (most of highland areas) and cultivation of crops which implies that at rural area of the study males dominate the economic activates both by participating and owning it. On other hand, females participate on non-productive economic activities such as cooking food, preparation of coffee at home, serving food, cleaning the home, and fetching water. Working on farms and the cultivation of food crops are men's (husbands) work.

In short, the general determinants and constraints of women's participation in economic activities were: finance problem, lack of business know how, women's dependency, social constraint traditional activities, and attitude of societies' and women themselves.

\section{Policy Recommendation}

Based on the results, the following policy implications are derived from this study which is expected to contribute to the in solving the main determinants of women's participation in economic activities.

$>$ The researchers assess that one of the major determinants of women's participation in economic activities at the study was lack of training given for women. Thus, we strongly recommend that the concerning body government, NGO or any institution should give business oriented training to increase the he participation of women in economic or business activities. 
$>$ The researcher found that a woman who has a few number of children has more probability of being participant in economic activates than a woman who has a large number of children. Therefore, the concerning body should give awareness about the importance of family planning, prepare associated policy with the issue, provide diversified family planning tools and reward the women who implement the policy as incentive.

$>$ The age interval of women has a significant role in driving economic activities. According to the survey obtained from descriptive analysis result, as the age of women increases between 30 and 64 years) and their participation in the economic activities increases, thus women should participate in the economic activities during their productive age.

$>$ Education is found to be one of the key elements to increase productivity of women even though it was insignificant in the model. So the government should make expand and diversify the education and it curriculum to increases production and productivity by women.

$>$ The plan and policy makers, implementers, decision makers should fill the gap between men and women in order to reduce labor division, unequal payment of salaries/wage, or others discrimination against women and abuse of women's basic human right.

$>$ Having access to credit can create opportunity for women to be involved in the economic activities. Thus, every woman, to be effective, needs access to credit services from different credit service providers whether the government, NGOs or any other private institutions as a source of finance which in turn empowers women to have a participation and benefit in the economic activities.

$>$ The government should develop comfortable source of finance for women by organizing and supporting the participation of women in economic activities.

$>$ Additionally, there was a problem of women's attitude toward business activities in general; thus, government (concerned body) should deeply create awareness on how to create business and success in the business process for women at the study area.

$>$ Rural women play a critical role in the agricultural sector, the government, NGO and others institutions should supports rural women to gain greater capacity to enhance and control assets, by provision of business trainings on entrepreneur ship and saving; an expansion small scale irrigation practices and rearing and fattening of livestock particular in Yabelo District.

$>$ Cultural and social activities such as marro should be continued by the current society and supported by government since it motivates women to work in group in order to poverty reduction and increasing the participation of women in economic activities at the study area.

In general, it is recommended that via awareness giving on attitude of women toward business, team work, family planning, education and training accessible for women should be improved by the government, NGOs and other stakeholders in order to enhance and increase women participation in economic activities at the study area.

\section{References}

Abiyot Eliyas Anbacha \& Darley Jose Kjosavik, (2018) Borana Women's Indigenous Social Network-Marro, In Building Household Food Security: Case Study from Ethiopia

Allan G. Bluman (2009), Elementary Statistics, 7th Edition, New York, USA

Aguilar (2011), From Age-Sets to Friendship Networks in Comparative Sociology, University of St. Andrews, Scotland.

Ayferam, Gashaw. 2015. "Assessment of the Roles and Constraints of Women in Economic Development of Ethiopia: The Case of Ambo Town Since 1991.” Journal of Political Sciences \& Public Affairs 03(01):1-11.

Belayineh Abeje(2015). The Determinant of Women's Participation in Economic Activities. Mekelle University, Mekelle, Ethiopia

Bilkisu Omar Dossa, Ibrahim Umar Mohammed and Ayuba Kuriwa Ndahi (2016), “Women in Irrigated Vegetable Production: Challenges and Opportunities (Case Study of Farmers in Plateau State, Nigeria).” 4(1):26-32.

Blau, F.D. \& Ferber, M. A. 1992.The Economics of Women, Men, and Work, $2^{\text {nd }}$ ed.New Jeresy 07632: Englewood Cliffs.

Bule Hora Women and Children Office, (2019). Bule- Hora, Ethiopia.

CSA, (2007). Population House Hold Size Censuses. Addis Ababa, Ethiopia. David

Damodar N. Gujarati and Dawn C. Porter (2009), Basic Econometrics, $5^{\text {th }}$ Edition, New York, USA

(DAW (2005), United Nations Division for the Advancement of Women, Addis Ababa, Ethiopia

Ellerman, (2014). Women's Labor Force Participation. USA

Dejene N. (2009). Gender and Culture in Southern Ethiopia: An Ethnographic Analysis of Guji-Oromo Women's Department of Anthropology, Miami University.

Gashaw Ayferam (2015). Assessment of the Roles and Constraints of Women in Economic Development of Ethiopia. Ambo, Ethiopia.

International Labor Organization (2013). United States.

International Labor Organization, (2015). USA. 
Korda, M. (1974). Male Chauvinism: How it works. London: Barrie and Jenkins.

K.A. and C.J. Wedman, (1999). Agricultural Extension for Women Farmers in Africa, Pretoria, South Africa.

Federal Negarit Gazeta, the Ministry of Finance, (1995) Proclamation of Powers and Duties of the Executive Organs of the Federal Democratic Republic of Ethiopia Proclamation No.4/1995." 19-8., Addis Ababa, Ethiopia

Mehara R. and Rojas M., (2008). Women's Food Security and Agriculture in Global Market Places.

Mesfin Mulu, (2013), Employment of Women, Addis Ababa University, Addis Ababa, Ethiopia.

Michael P. Todaro and Stephen C. Smith Economic Development, New 11th edition York University, The George Washington University USA.

Ministry of Women Affairs (2015), Addis Ababa, Ethiopia

National Committee on Traditional Practice of Ethiopia, Old Beyond Imaginings: Ethiopia Harmful Traditional Practices, 2003

The Telegraph (2015). Safari holidays: Africa's leading ladies. 8 March. Available at http:/www.telegraph.co.uk/travel/destinations/africa/articles/Safari-holidaysAfricas-leading-ladies/ (accessed 20 February 2017)

Oakley, A. (1981). Subject Women. Oxford: Martin Robertson Publishers.

Saito K., (1994). Raising the Productivity of Women Farmers in Sub-Saharan Africa.

Tadesse Jaleta. 2013. Children and Oral Tradition Among the Guji-Oromo

UN, 2016 Economic Development. In Africa. New York, USA

UN, 2017 Economic Development. In Africa. New York, USA

UNICEF, 2017 Analysis of Children and Women in Ethiopia, Addis ababa

World Bank, (2012). Enhancing Women's Economic Development, Washington DC, USA.

Yabelo Women and Children Office, (2019). Yabelo, Ethiopia.

\section{APPENDICES}

Appendix I: Population Size of the Study Area

Source: CSA, 2007

Appendix II: The Estimated Population Size Sex for Eleven Years

(the important point in the process of sample size determination)

Appendix III: Questionnaire- in English

Appendix V: Test of Correlation among Independent Variables and Marginal Effect

- cor educ_leve1_wmn age_wmn govt_policy avai1_credit numberchldrn afarm_action training_wmn marita1_status_wmn wi11ingness_tmwrk_wm n (obs=374)

\begin{tabular}{|c|c|c|c|c|c|c|c|c|c|}
\hline & educ_1 n n & age_wmn & jovt_p y & avai1_ & number $\sim n$ & afarm_ n & traini & marita r & villin n \\
\hline $\begin{array}{r}\text { educ_leve1 n } \\
\text { age_wmn } \\
\text { govt_po1icy } \\
\text { avai1_credit } \\
\text { numberch1drn } \\
\text { afarm_action } \\
\text { training_wmn } \\
\text { marital_st n } \\
\text { wi11ingnes n }\end{array}$ & $\begin{array}{r}1.0000 \\
0.0874 \\
0.2841 \\
-0.0757 \\
-0.0900 \\
0.1862 \\
0.0832 \\
-0.2084 \\
0.1818\end{array}$ & $\begin{array}{r}1.0000 \\
0.0462 \\
0.2284 \\
0.0930 \\
0.0196 \\
0.1448 \\
-0.1479 \\
0.1635\end{array}$ & $\begin{array}{r}1.0000 \\
0.0490 \\
-0.1152 \\
0.0431 \\
0.1356 \\
-0.2735 \\
0.2703\end{array}$ & $\begin{array}{r}1.0000 \\
-0.0631 \\
0.0944 \\
0.2673 \\
-0.3005 \\
0.2573\end{array}$ & $\begin{array}{r}1.0000 \\
-0.1620 \\
0.0519 \\
0.2153 \\
-0.0764\end{array}$ & $\begin{array}{r}1.0000 \\
0.0572 \\
-0.3039 \\
0.2457\end{array}$ & $\begin{array}{r}1.0000 \\
-0.2357 \\
0.2921\end{array}$ & $\begin{array}{r}1.0000 \\
-0.4742\end{array}$ & 1.0000 \\
\hline
\end{tabular}

Source: calculated by the researcher

. $\mathrm{mfx}$

Marginal effects after logistic

$y=\operatorname{Pr}($ particista_womeninbusns) (predict)

$=.74889773$

\begin{tabular}{|c|c|c|c|c|c|c|c|}
\hline variable & $d y / d x$ & std. Err. & z & $P>|z|$ & $95 \%$ & C.I. & $x$ \\
\hline 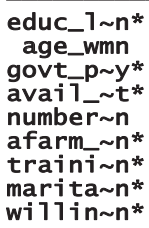 & $\begin{array}{r}.1730107 \\
.0241846 \\
.0256139 \\
.3184322 \\
-.0948442 \\
.2000213 \\
.3798834 \\
-.7897667 \\
.3856288\end{array}$ & $\begin{array}{l}.1058 \\
.0059 \\
.09043 \\
.09668 \\
.02272 \\
.11189 \\
.09431 \\
.06708 \\
.10134\end{array}$ & $\begin{array}{r}1.64 \\
4.10 \\
0.28 \\
3.29 \\
-4.17 \\
1.79 \\
4.03 \\
-11.77 \\
3.81\end{array}$ & $\begin{array}{l}0.102 \\
0.000 \\
0.777 \\
0.001 \\
0.000 \\
0.074 \\
0.000 \\
0.000 \\
0.000\end{array}$ & $\begin{array}{r}-.034355 \\
.012614 \\
-.151632 \\
.128934 \\
-.139378 \\
-.019282 \\
.19504 \\
-.921236 \\
.187\end{array}$ & $\begin{array}{r}.380376 \\
.035755 \\
.202859 \\
.50793 \\
-.050311 \\
.419325 \\
.564726 \\
-.658297 \\
.584258\end{array}$ & $\begin{array}{l}.729947 \\
35.8583 \\
.510695 \\
.695187 \\
4.50267 \\
.729947 \\
.687166 \\
.264706 \\
.665775\end{array}$ \\
\hline
\end{tabular}

(*) $d y / d x$ is for discrete change of dummy variable from 0 to 1

Source: calculated by the researcher

Appendix VI: Person Residual

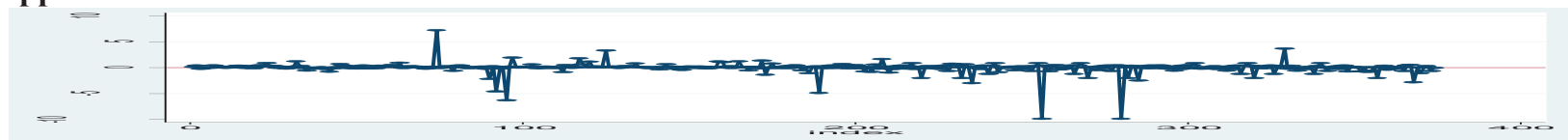


Source: calculated by the researcher Appendix VII: Hypothesis Testing

Source: calculated by the researcher

Appendix VIII: Fitstat Test 